Original Research Paper

\title{
Growth and Graduation of Vannamei Shell Life (Litopenaeus Vannamei) with Feeding Tray (ANCO) System in AV 8 Lim Shrimp Organization (LSO) in Sumbawa District
}

\author{
Syamsul Bahri ${ }^{1 *}$, Dwi Mardhia ${ }^{1}$, Osi Saputra ${ }^{1}$ \\ ${ }^{1}$ Program Studi Manajemen Sumberdaya Perairan, FAPETKAN Universitas Samawa (UNSA), Indonesia;
}

\author{
Article History \\ Received : April $20^{\text {th }}, 2020$ \\ Revised : July $24^{\text {th }}, 2020$ \\ Accepted : August $5^{\text {th }}, 2020$ \\ Published : August $11^{\text {th }}, 2020$ \\ *Corresponding Author: \\ Syamsul Bahri, \\ Program Studi Manajemen \\ Sumberdaya Perairan) \\ FAPETKAN Universitas Samawa \\ (UNSA), Indonesia; \\ Email: ersyambamsp@gmail.com
}

\begin{abstract}
Absract: Vannamei shrimp species look for lunch and dinner. These properties need to be known related to the amount of feed and frequency of feeding to be given. Because wasted feed is expensive and can reduce water quality, optimizing feeding practices is an important issue in shrimp culture management. The use of some ANCOs is intended to monitor feed consumption and estimate feed adjustments. So it is necessary to conduct research on the growth and graduation of vannamei shrimp (Litopenaeus Vannamei) with the feeding tray (ANCO) system in Av 8 Lim Shrimp Organization (LSO) in Sumbawa Regency. The method used in this research is descriptive method, namely research based on reality and the facts of the situation as it is. The results showed that the amount of feed every week or sampling is always different, this is because the amount of feed adjusted to the addition of shrimp growth every sampling. Addition and reduction of feeding is adjusted to the results of checking feed consumption on ANCO, adding the amount of feeding is done if when checking ANCO there is no feed left. Reduction in the number of gifts is done if when checking ANCO still left feed. In the 8th sampling the amount of feed decreased to $38 \mathrm{~kg}$, this was due to the first partial harvest. In the 10th sampling is the lowest amount of feeding which is $30 \mathrm{~kg}$, this is due to the second partial harvest, but in the 11th sampling the number of feeding again increased so that the shrimp could grow to its maximum potential during panentotal.
\end{abstract}

Keywords: growth; Litopenaeus Vannamei; feeding tray; Sumbawa;

\section{Pendahuluan}

Kabupaten Sumbawa merupakan wilayah perairan pesisir dan lautan berpeluang dalam mengembangkan potensi pesisir dan lautan untuk berbagai kegiatan perikanan baik penangkapan ikan maupun kegiatan budidaya, yang memberikan kontribusi besar dalam peningkatan pertumbuhan ekonomi dan kesejahteraan masyarakat (Dinas Kelautan dan Perikanan, 2014).

Menurut data Kabupaten Sumbawa dalam angka tahun 2019, pada tahun 2018 terdapat 7 izin usaha budidaya perikanan, sedangkan pada tahun 2019 terdapat 52 izin usaha budidaya perikanan. Hal ini, terlihat bahwa kegiatan budi daya perikanan sangat menjanjikan keuntungannya.

Di Indonesia sendiri lokasi tambak adalah di Sumbawa, Nusa Tenggara Barat. Salah satu perusahaan salah satunya Lim Shrimp Organization (LSO). Lim Shrimp Organization (LSO) adalah produsen udang dan ikan global yang beroperasi di beberapa negara di Asia, salah satunya adalah Indonesia. Lim Shrimp Organization (LSO) hingga saat ini, sudah berhasil menjadi operator tambak udang terbesar di dunia. Dalam kurun periode 1987 hingga 2007 hingga sekarang, Lim Shrimp Organization (LSO) sudah mengelola hampir 12 Aqua Village di seluruh dunia diantaranya Indonesia, Qatar, Arab Saudi, Oman, Malaysia, Cina, Thailand, Filipina, Palau, Maladewa, dan lainnya (Halim, 2019).

Budidaya merupakan salah satu kegiatan alternatif dalam meningkatkan produksi perikanan (Hikmayani $e t$ al., 2012; Karuppasamy et al., 2013). Di Indonesia kepadatan budidaya udang yang umum dilakukan di berbagai daerah berkisar $80-100$ ind./m2 udang vaname dan dapat ditingkatkan hingga 244 ind./m2, yang mampu menghasilkan produksi 37,5 ton/ha/siklus (Poernomo, 2004).

Sedangkan menurut Mangampa, et al (2010: 352) produksi yang tinggi tidak selamanya diikuti oleh keuntungan yang tinggi. Produksi yang tinggi akan berdampak kepada beban limbah yang dihasilkan baik 
oleh sisa pakan apabila rasio konversi pakan tinggi, maupun kotoran udang.

Jenis udang Vaname merupakan salah satu jenis udang yang sering dibudidayakan oleh masyarakat maupun perusahaan. Hal ini disebabkan udang tersebut memiliki prospek dan profit yang menjanjikan (Babu et al., 2014).

Permasalahan utama kegagalan yang sering ditemukan dalam produksi udang vaname adalah buruknya kualitas air selama masa pemeliharaan terutama pada tambak. Padat tebar yang tinggi dan pemberian pakan yang banyak dapat menurunkan kondisi kualitas air (Arsad, Sulastri et al., 2017: 2).

Syarat terlaksananya kegiatan budidaya adalah adanya organisme yang dibudidayakan, media hidup organisme, dan wadah/tempat budidaya. Budidaya udang harus memperhatikan faktor-faktor penting terutama pakan udang. Pakan udang komposisinya harus mengandungan protein, karbohidrat, lemak dan lainlainnya atau disesuaikan dengan kebutuhan udang, sehingga dapat mencapai pertumbuhan yang optimum. Jenis udang vannamei mencari makan siang dan malam hari (diurnal dan nokturnal) sangat rakus. Sifat ini perlu untuk diketahui berkaitan dengan jumlah pakan dan frekuensi pemberian pakan yang akan diberikan. Sebab pakan yang terbuang adalah sesuatu yang mahal dan dapat mengurangi kualitas air, maka pengoptimalan praktik pemberian pakan merupakan hal penting dalam masalah manajemen budidaya udang (Nunes \& Suresh, 2001).

Penggunaan anco diharapkan sebagai alat bantu dalam mengestimasi tingkat konsumsi pakan harian untuk penyesuaian kebutuhan pakan dari udang yang dipelihara. Zeigler \& Horton (2015) mengemukakan bahwa anco biasanya digunakan untuk mencegah terjadinya overfeeding dalam sistem produksi budidaya.

Cing \& Limsuwan (2012) mengemukakan bahwa metode pemberian pakan secara langsung (disebar) digunakan hampir di seluruh tambak udang di dunia dengan jalan memberikan pakan secara langsung sebanyak 94-97\% dan menyisakan 3-6\% dari dosis pakan yang akan dibagi sebagai sampel dianco. Alokasi biaya pakan pada budidaya udang dapat mencapai $60-70$ $\%$ dari total biaya produksi (Rangka, et al., 2012: 142).

Nudes \& Suresh (2001) menyatakan bahwa penggunaan beberapa anco dimaksudkan untuk memantau konsumsi pakan dan perkiraan penyesuaian ransum. Strategi pengelolaan pakan (feeding program) melalui teknik pergiliran pakan merupakan salah satu upaya untuk penghematan biaya pakan. Pergiliran pakan yang dimaksud yaitu pakan berprotein tinggi digilir dengan pakan berprotein rendah karena adanya selisih harga di antara kedua jenis pakan didasarkan pada selisih kandungan proteinnya (Mansyur \& Suwoyo, 2012; Mansyur et al., 2013). Pengurangan proporsi protein pada pakan tanpa mengurangi laju pertumbuhan pada spesies yang dibudidayakan dapat berpengaruh pada efisiensi biaya produksi sehingga pendapatan akan semakin tinggi.

Pengamatan sistem pemberian pakan dari sejumlah anco bukan merupakan ukuran yang memadai dari konsumsi pakan yang sebenarnya, terutama di kolam besar. Ada banyak variasi dari hari ke hari yang mempengaruhi dalam konsumsi pakan misalnya fluktuasi kualitas air, langit mendung, siklus lunar, aktivitas molting, dan ketersediaan makanan alami. Budidaya udang pada umumnya selama ini, pemberian pakan hanya ditebar saja dan tidak bisa dipantau seberapa banyak pakan yang dikonsumsi oleh udang dan alat kontrolnya hanya anco (Syafaat, dkk. 2016).

Dengan adanya beberapa pendapat perlu dilakukan penelitian tentang pertumbuhan dan kelulusan hidup udang vannamei (Litopenaeus Vannamei) dengan sistem feeding tray (anco) di Av 8 Lim Shrimp Organization (Lso) Di Kabupaten Sumbawa.

\section{Bahan dan Metode}

\section{Tempat dan Waktu}

Penelitian ini dilakukan di tambak udang Av8 Lim Shrimp Organization (LSO), Desa Gontar, Kecamatan Alas Barat, Kabupaten Sumbawa. Penelitian dilakukan selama Tujuh bulan dari bulan Februari-Agustus 2019.

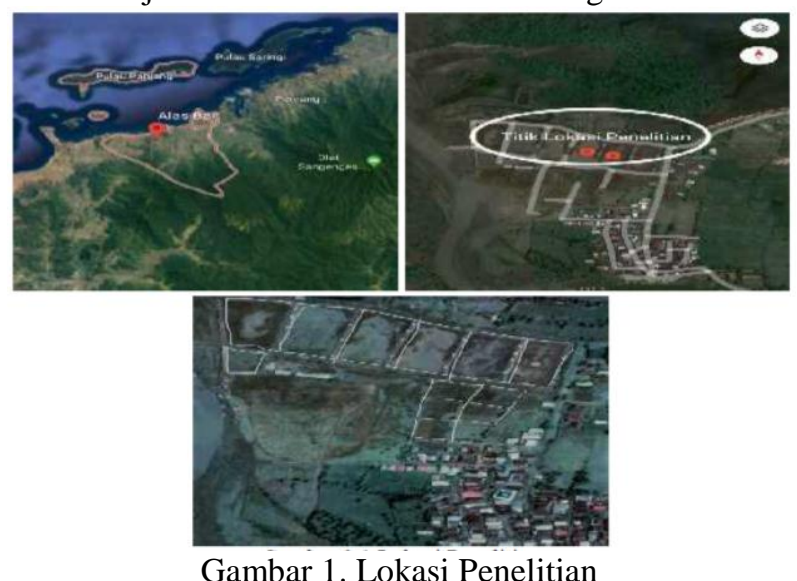

Metode

Metode yang digunakan dalam penelitian ini adalah metode deskriptif, yaitu penelitian berdasarkan realitas dan fakta keadaan di lapangan secara apa adanya.

Persiapan yang dilakukan selama penelitian berlangsung terdiri atas beberapa tahap: Pertama, persiapan tambak meliputi, pembersihan tiram dan lumut di sekitar kolam. Setelah itu, dilakukan pengeringan pada kolam selama 3-4 hari agar hama yang dapat mengganggu proses budidaya udang. Pengeringan dilakukan dengan bantuan sinar matahari. Luas kolam yang digunakan dalam penelitian adalah $1.500 \mathrm{~m}^{2}$; kedua, persiapan anco 
dilakukan setelah kolam sudah siap untuk digunakan dengan jumlah anco 12 buah ukuran 80 x $80 \mathrm{~cm}$. Peletakan anco dilakukan sebelum proses pengisisan air pada kolam budidaya. Hal ini, untuk memudahkan pemasangan anco pada setiap sisi kolam. Anco yang digunakan diletakkan sebanyak tiga buah anco di setiap sisi kolam, berguna sebagai media pemberian pakan.

Ketiga, pengisian air kolam budidaya, setelah proses pengeringan selesai dan tambak sudah siap, kemudian dilakukan pengisian air dengan ketingian 80 $\mathrm{cm}$. Air pada tambak dibiarkan selama 7 hari agar plankton yang akan digunakan sebagai pakan alami dan indikator kestabilan lingkungan dapat tumbuh dengan baik, kemudian baru dilakukan penambahan air hingga ketinggian $100 \mathrm{~cm}$; keempat, perhitungan jumlah benur, perhitungan jumlah benur dilakukan dengan mengambil satu kantong benur, kemudian benur diletakan ke dalam bak yang sudah diisi dengan air, proses perhitungan dilakukan dengan bantuan sendok berwarna putih agar memudahkan melihat benur yang berukuran sangat kecil. Setelah proses perhitungan selesai, benur akan dikembalikan ke dalam petak.

Kelima, penebaran setelah air tambak sudah siap, maka dilakukan proses aklimatisasi terlebih dahulu sebelum benur ditebar ke dalam tambak. Dengan cara meletakan kantong yang berisi benur pada permukaan air tambak dan dibiarkan mengapung selama 15-30 menit. Aklimatisasi dilakukan agar benur mampu menyesuaikan diri terhadap suhu dan salinitas air tambak, untuk mengurangi resiko kematian benur saat penebaran dilakukan. Benur yang digunakan yaitu post larva 8-11 (PL-11); Keenam pemeliharaan udang vannamei (litopenaeus vannamei), proses pemeliharaan udang vannamei (Litopenaeus vannamei) dilakukan selama 1 siklus atau 3 bulan dimulai setelah penebaran benur. Monitoring pertumbuhan dilakukan setelah udang berumur 35 hari dengan mengunakan metode sampling untuk mengetahui pertambahan berat dan ukuran udang vannamei selama penelitian. Saat udang berumur 70 hari dilakukan panen persial untuk mengurangi jumlah kepadatan udang. Namun 2 minggu setelah panen persial dilakukan panen total sehingga mendapatkan laju pertumbuhan yang maksimal dari awal penebaran hingga pemanenan.

Ketujuh pemberian pakan, dilakukan setiap hari sebanyak 5 kali sehari pada jam 07:00, 11:00, 13:00, 16:00, 21:00. Rentang waktu pemberian pakan pada siang hari lebih dekat dari pada rentang waktu pemberian pakan pagi maupun malam hari. Sebab, nafsu makan udang lebih tinggi pada siang hari dari pada pagi maupun malam hari. Jenis pakan yang digunakan pakan irawan dengan media pemberian pakan yang menggunakan anco. Pada sistem ini, pakan diletakan terlebih dahulu ke dalam anco, selanjutnya anco yang sudah terisi pakan diturunkan ke dasar petak; kedelapan sampling panjang dan bobot, dilakukan sebanyak 11 kali setiap hari minggu dan dilakukan sekali dalam seminggu dari awal sampling. Sampling dilakukan dengan cara mengambil sampel udang secara acak dan tergantung jumlah sampel yang naik pada jala. Pengukuran panjang udang diukur menggunakan pengaris dari ujung ekor sampai dengan ujung kepala. Sedangkan pengukuran bobot dilakukan dengan ditimbang dan dihitung bobotnya.

Kesembilan panen, pemanenan dilakukan ketika udang berumur maksimal 105 hari. Pemanenan dilakukan dengan cara menguras air melalui outlet. Di outlet dipasangkan jaring agar udang tidak ke luar pada saat pengurasan air. Pengurasan air dilakukan sampai dengan ketinggian 5-10 cm, untuk memudahkan penangkapan udang menggunakan jala.

\section{Teknik Pengumpulan Data}

Pengumpulan data dalam penelitian ini ada dua yaitu data primer dan data sekunder. Data Primer merupakan data yang diperoleh secara langsung, diamati, dan dicatat melalui prosedur dan teknik pengambilan data yang berupa observasi. Pengambilan data dilakukan dengan proses sampling menggunakan jala setiap seminggu sekali sejak umur 35 hari pada tambak sistem pemberian pakan feeding tray (anco), udang yang didapatkan ditimbang menggunakan timbangan dan dilakukan perhitungan jumlah udang yang didapat dan dicatat untuk mengetahui laju pertumbuhan.

Alat dan bahan yang dibutuhkan yaitu Anco fungsi Wadah pemberian pakan; Kincir fungsi Pemberi sirkulasi air tambak; Insitu fungsi Mengukur kualitas air; HP fungsi Dokumentasi penelitian; Udang fungsi Vannamei PL 8-11 Objek yang diteliti; Penggaris fungsi Menggukur panjang udang; Timbangan fungsi Menimbang pakan; Pakan Irawan fungsi Pakan utama; Air Tambak fungsi Media pemeliharaan (Sumber: Analisis Data, 2019).

Pengukuran parameter kualitas air dilakukan dengan menggunkan alat in-situ. Pengukuran dilakukan dengan cara alat in-situ dinyalakan kemudian di sambungkan mengguakan bloutooth ke HP, lalu celupkan alat in-situ ke dalam air tambak, maka nilai parameter yang diukur meliputi Suhu, Ph, Salinitas, DO (Oksigen terlarut) akan muncul secara otomatis dilayar HP.

Sedangkan data sekunder yaitu data yang diproleh penelitian dari sumber penelitian yang sudah ada seperti jurnal, skripsi dan dokumen Lim Shrimp Organization (LSO).

\section{Analisis Data}

Analisis data dalam penelitian ini adalah deskriptif kualitatif. Analisis data deskripftif kualitatif dilakukan dengan cara mendeskripsikan fenomena yang ada di lapangan atau melakukan pengamatan secara langsung terhadap objek yang akan diteliti sehingga mendapatkan gambaran yang jelas mengenai objek sasaran. 
Parameter yang akan diuji untuk melihat laju pertumbuhan udang vannamei dengan sistem pemberian pakan feeding tray (anco) ialah:

\section{a. Mean Body Weight (MBW)}

Mean Body Weight (MBW), merupakan berat ratarata udang dari hasil sampling. MBW dapat di hitung sebagai berikut (Hermawan, 2012):

$$
\text { MBW }=\frac{\text { Berat Total Sampel Udang }}{\text { Jumlah Sampel udang }}
$$

\section{b. Average Daily Growth (ADG)}

Average Daily Growth (ADG) adalah pertambahan berat harianrata-rata udang dalam suatu periode waktu tertentu sehingga dapat digunakan untuk mengatahui kecepatan pertumbuhan udang. Average Daily Growth (ADG) dapat dihitung dengan rumus sebagai berikut (Haliman dan Adijaya, 2005).

$$
\mathrm{ADG}=\frac{M B W \text { Saat Ini }-M B W \text { Sebelumnya }}{\text { Interval Waktu Sampling }}
$$

\section{c. Spesific Grow Rate (SGR)}

Spesific Grow Rate (SGR) pertumbuhan spesifik yaitu pertumbuhan Panjang harian udang, dihitung dengan menggunakan rumus (Zonneveld et al. 2007).

Keterangan:

$$
\mathrm{SGR}=\frac{\operatorname{In} L t-\operatorname{In} L o}{t} \times 100 \%
$$

$$
\begin{aligned}
\mathrm{SGR} & =\text { Pertumbuhan spesifik (\%) } \\
\mathrm{Lt} & =\text { Panjang akhir }(\mathrm{g}) \\
\mathrm{L} 0 & =\text { Panjang awal }(\mathrm{g}) \\
\mathrm{T} & =\text { Waktu (hari) }
\end{aligned}
$$

\section{d. Perhitungan FCR (Feed Convertion Ratio)}

Perhitungan konversi pakan dilakukan dengan menggunakan rumus dari (Supono \& Wardiyanto 2008) sebagai berikut:

Keterangan:

$$
\mathrm{FCR}=\frac{F}{\text { Biomass }}
$$

$$
\begin{array}{ll}
\mathrm{FCR} & =\text { Feed Convertion Ratio } \\
\mathrm{F} & =\text { Jumlah pakan komulatif akhir panen }(\mathrm{Kg}) \\
\text { Biomass } & =\text { Udang akhir }(\mathrm{kg})
\end{array}
$$

\section{e. Survival Rate (SR)}

Pengukuran tingkat kelulus hidupan dilakukan dengan menghitung jumlah penebaran pada awal penebaran dan jumlah yang hidup ketika panen diakhir masa budidaya tambak. Menurut Haliman dan Adiwijaya (2005), rumus untuk menghitung tingkat kelulusan hidup (SR) adalah sebagai berikut:

Keterangan:

$$
\mathrm{SR}=\frac{N t}{N o} \times 100 \%
$$

$$
\text { SR = Survival Rate }(\%)
$$

$$
\begin{array}{ll}
\mathrm{Nt} & =\text { Jumlah udang saat panen } \\
\mathrm{No} & =\text { Jumlah tebar awal udang }
\end{array}
$$

\section{Hasil dan Pembahasan}

\section{Pemberian Pakan Sistem FeedingTray (anco)}

Pemberian pakan sistem feeding tray yang merupakan sistem pemberian pakan menggunakan anco sebagai media pemberian pakan. Pada sistem ini, pakan diletakkan terlebih dahulu ke dalam anco, selanjutnya anco yang sudah terisi pakan tersebut diturunkan ke dasar petak. Kemudian, udang mengkonsumsi pakan yang ada di dalam anco. Jumlah pakan yang diberikan dari awal tebar sampai akhir pemeliharaan dapat dilihat pada Tabel 1 di bawah ini:

Tabel.1 Jumlah pemberian pakan

\begin{tabular}{|c|c|c|c|c|c|c|c|c|c|c|c|}
\hline \multicolumn{11}{|c|}{ Jumlah Pakan Perhari $(\mathrm{kg})$} \\
\hline Sampling & 1 & 2 & 3 & 4 & 5 & 6 & 7 & 8 & 9 & 10 & 11 \\
\hline $\begin{array}{c}\text { Jumlah } \\
\text { Pakan }\end{array}$ & 25 & 30 & 33 & 37 & 39 & 44 & 46 & 38 & 39 & 30 & 32 \\
\hline
\end{tabular}

Berdasarkan Tabel 1 jumlah pakan setiap minggu atau sampling selalu berbeda, hal ini disebabkan karena jumlah pemberian pakan disesuaikan dengan penambahan pertumbuhan udang setiap sampling. Penambahan dan pengurangan pemberian pakan disesuaikan dengan hasil pengecekan konsumsi pakan pada anco, penambahan jumlah pemberian pakan dilakukan jika saat pengecekan anco tidak tersisa pakan. Pengurangan jumlah pemberian dilakukan jika saat pengecekan anco masih tersisa pakan.

Pada sampling ke-8 jumlah pemberian pakan mengalami pengurangan menjadi $38 \mathrm{~kg}$, hal ini karena dilakukannya panen parsial yang pertama. Pada sampling ke-10 merupakan jumlah pemberian pakan paling rendah yaitu sebesar $30 \mathrm{~kg}$ hal ini terjadi karena dilakukannya panen parsial kedua, namun pada sampling ke-11 jumlah pemberian pakan kembali meningkat agar udang mampu tumbuh dengan maksimal pada saat panentotal.

\section{Laju Perumbuhan Udang Vannamei (Litopenaeus vannamei) di Tambak Av8 Pada Petak 7}

\section{Pertumbuhan Panjang}

Berdasarkan hasil penelitian, nilai pertumbuhan panjang udang vannamei (Litopenaeus vannamei) hasil pengambilan data selama 70 hari menunjukan adanya pertumbuhan panjang $(\mathrm{cm})$. Rata-rata panjang udang vannamei (Litopenaeus vannamei)

Berdasarkan hasil sampling pertumbuhan panjang udang vannamei (Litopenaeus vannamei) dapat dilihat pada Gambar 2 sebagai berikut: 


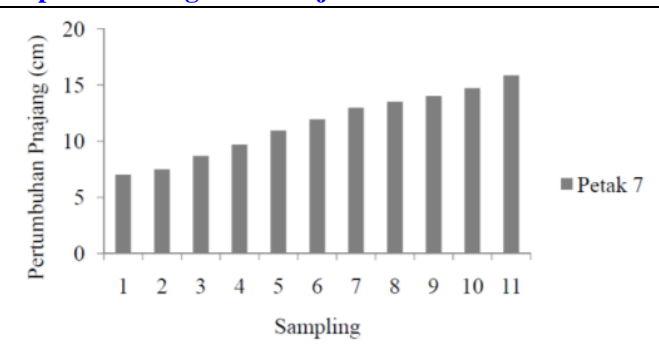

Gambar 2 Pertumbuhan Panjang Udang Vannamei (Litopenaeus vannamei)

Berdasarkan Gambar 2 dapat dilihat pada sampling pertumbuhan panjang udang vannamei (Litopenaeus vannamei). Pertumbuhan panjang pada sampling ke-1 sebesar 6,82 cm. Pada sampling ke-11 memiliki nilai panjang yang meningkat cukup tinggi yaitu sebesar 15,50 $\mathrm{cm}$.

Menurut Effendi (2003) pertumbuhan panjang ratarata yang baik sebesar $13,50 \mathrm{~cm} /$ minggu. Sedangkan Gunarto dan Hendrajat (2008) mendapatkan laju pertumbuhan harian udang vannamei berkisar antara 12,01-15,80 cm/minggu. Berdasarkan hasil nilai pertumbuhan total panjang rata-rata yaitu sebesar 11,05 $\mathrm{cm} /$ minggu. Hasil total pertumbuhan panjang rata-rata dapat disimpulkan bahwa pemberian pakan mengunakan sistem feeding tray (anco) tidak efektif dalam meningkatkan pertumbuhan udang vannamei (Litopenaeus vannamei). Rendahnya pertumbuhan panjang pada pemberian pakan sistem feeding tray (anco) dikarenakan pola pemberian pakan yang kurang tepat.

Menurut Khasani (2013), Penyampaian informasi rangsangan oleh rambut-rambut aestetac sebagai organ sensorik, menurunnya rangsangan yang diterima rambutrambut aestetac menyebabkan menurunnya respon udang dalam mencari dan mendekati pakan serta respon udang dalam menemukan dan memakan pakan yang diberikan. Supito (2017) menambahkan agar pertumbuhan udang vannamei yang dibudidayakan di tambak dapat tumbuh dengan baik, maka pola pemberian pakan harus tepat dan cukup jumlahnya

\section{Pertumbuhan Berat (MBW)}

Mean Body Weight (MBW) merupakan berat udang dari hasil sampling. Berdasarkan hasil penelitian nilai pertumbuhan berat udang vannamei (litopenaeus vannamei) hasil pengambilan data selama 70 hari menunjukan adanya pertumbuhan berat udang (gram). Rata-rata berat udang vannamei (Litopenaeus vannamei)

Berdasarkan hasil sampling pertumbuhan berat udang vannamei (Litopenaeus vannamei) dapat dilihat pada gambar 3 sebagai berikut:

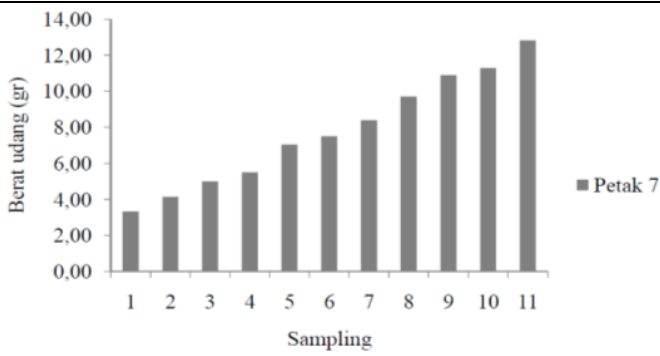

Gambar 3 Petumbuhan Berat Udang Vannamei (Litopenaeus vannamei)

Berdasarkan hasil sampling berat udang vannamei pada Gambar 3, sampling pertama dilakukan pada doc 35 hari, berat yang didapat yaitu 3.33 gram. Berat udang vannamei (Litopenaeus vannamei) mengalami peningkatan yang cukup tinggi pada doc 105 hari dengan pertumbuhan berat 12.80 gram.

Menurut (Effendie. 2003) yang menyatakan pertumbuhan udang yang baik sebesar 1-3 gram/minggu. Sedangkan Supono (2017) berpendapat udang vannamei dapat tumbuh dengan baik dengan tingkat pertumbuhan 12,5 gram/ minggu. Total pertumbuhan berat rata-rata setiap sampling yaitu 0,86 gram/minggu. Dari hasil total pertumbuhan berat rata-rata dapat disimpulkan bahwa pemberian pakan mengunakan sistem feeding tray (anco) tidak efektif dalam meningkatkan pertumbuhan udang vannamei (Litopenaeus vannamei). Hal ini disebabkan oleh, pakan yang diberikan mengguakan sistem feeding tray tidak dapat dimakan secara merata oleh udang vannamei. Kekurangan pakan menyebabkan rendahnya pertumbuhan pada udang akibat kurangnya energi yang diperoleh dari pakan untuk kegiatan metabolisme dan kelebihan pakan juga dapat menyebabkan pertumbuhan rendah karena memerlukan energi yang besar untuk proses metabolisme sehingga pertumbuhan udang vaname terhambat akibat kekurangan energi. Menurut pendapat Khasani (2013) penyampaian informasi rangsangan oleh rambut-rambut aestetac sebagai organ sensorik, menurunnya rangsangan yang diterima rambut-rambut aestetac menyebabkan menurunnya respon udang dalam mencari dan mendekati pakan serta respon udang dalam menemukan dan memakan pakan yang diberikan. Supito (2017) menambahkan tidak semua udang memiliki pergerakan yang aktif dan cenderung berdiam diri pada dasar petak. Sehingga pakan yang diberikan menggunakan anco tidak termakan secara merata oleh udang vannamei. Hal ini, mempengaruhi nilai laju pertumbuhan pada udang.

\section{Pertumbuhan Panjang Harian (SGR)}

Spesific Grow Rate (SGR) merupakan pertumbuhan panjang harian, hasil pengambilan data selama 70 hari menunjukan adanya pertumbuhan panjang harian udang vannamei (Litopenaeus vannamei). 
Berdasarkan hasil perumbuhan panjang harian udang vannamei (Litopenaeus vannamei) dapat dilihat pada Gambar 4 sebagai berikut:

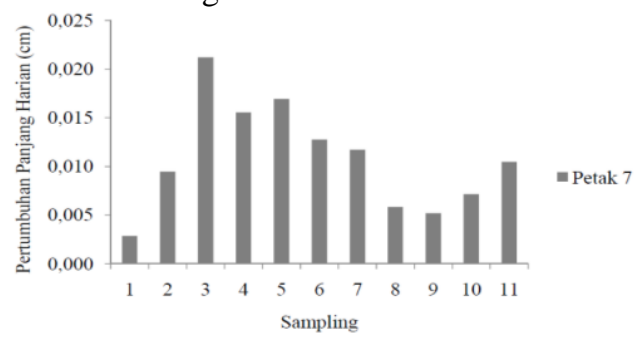

Gambar 4 Petumbuhan Panjang Harian Udang

Berdasarkan hasil pertumbuhan panjang harian udang vannamei (Litopenaeus vannamei) pada Gambar 4 laju pertumbuhan panjang harian sampling ke-1 sebesar $0,003 \mathrm{~cm}$, berdasarkan pengecekan konsumsi pakan udang vannamei pada anco menunjukan konsumsi pakan rendah karena udang tidak aktif bergerak mencari makan. Pada sampling ke-11 pertumbuhan panjang harian yang cukup tinggi yaitu $0,010 \mathrm{~cm}$.

Menurut (Effendie. 2003) yang menyatakan pertumbuhan rata-rata panjang harian udang yang baik sebesar $0,24 \mathrm{~cm} /$ hari. Gunarto dan Hendrajat (2008) mendapatkan laju pertumbuhan harian udang vannamei berkisar antara 0,19-0,26 cm/hari. Berdasarkan hasil sampling total rata-rata pertumbuhan panjang harian udang vannamei sebesar $0,0108 \mathrm{~cm} /$ hari. Berdasarkan hasil pengukuran pertumbuhan panjang harian udang vannamei dapat disimpulkan bahwa pemberian pakan sistem feedimg tray (anco) tidak efektif untuk pertumbuhan udang vannamei. Menurut pendapat (Effendie, 2003) Bahwa pertumbuhan udang dipengaruhi oleh keturunan, jenis kelamin, umur, kepadatan, parasit dan penyakit serta kemampuan memanfaatkan makanan. Rendahnya pertumbuhan udang vannamei (Litopenaeus vannamei) terjadi karena kurang optimalnya konsumsi pakan udang vannamei. Kekurangan pakan menyebabkan rendahnya.

Pertumbuhan pada udang akibat kurangnya energi yang diperoleh dari pakan untuk kegiatan metabolisme dan kelebihan pakan juga dapat menyebabkan pertumbuhan rendah karena memerlukan energi yang besar untuk proses metabolisme sehingga pertumbuhan udang vaname terhambat akibat kekurangan energi. Pakan yang diberikan menggunakan sistem feeding tray tidak termakan secara merata. Menurut pendapat Khasani (2013) penyampaian informasi rangsangan oleh rambut-rambut aestetac sebagai organ sensorik, menurunnya rangsangan yang diterima rambut-rambut aestetac menyebabkan menurunnya respon udang dalam mencari dan mendekati pakan serta respon udang dalam menemukan dan memakan pakan yang diberikan. Sutanto (2005) menambahkan tidak semua udang memiliki pergerakan yang aktif dan cenderung berdiam diri pada dasar petak.
Sehingga pakan yang diberikan menggunakan anco tidak termakan secara merata oleh udang vannamei. Hal ini, mempengaruhi nilai laju pertumbuhan pada udang.

\section{Pertumbuhan Berat Harian (ADG)}

Average Daily Growth (ADG) merupakan pertumbuhan berat harian pada. hasil pengambilan data selama 70 hari menunjukan adanya pertumbuhan berat harian udang vannamei.

Berdasarkan hasil pertumbuhan berat harian udang vannamei (Litopenaeus vannamei) dapat dilihat pada Gambar 5 sebagai berikut:

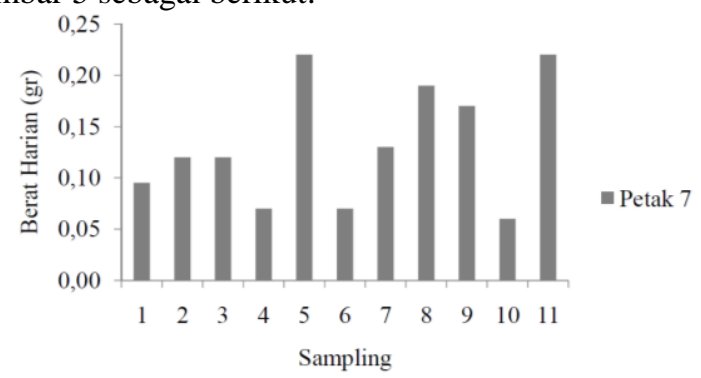

Gambar 5 Petumbuhan Berat Harian Udang Vannamei (Litopenaeusvannamei)

Hasil pertumbuhan berat harian udang vannamei (Litopenaeus vannamei) berdasarkan Gambar 5 pada sampling ke-1 menunjukan pertumbuhan yang rendah yaitu 0,10 gram. Pada sampling ke-11 pertumbuhan berat harian mengalami peningkatan yang cukup tinggi yaitu 0,22 gram.

Menurut Subyakto et al. (2009), pertumbuhan ratarata berat harian udang yang baik sebesar $0,14 \mathrm{~g} / \mathrm{hari}$. Gunarto dan Hendrajat (2008) mendapatkan laju pertumbuhan harian udang vannamei berkisar antara $0,14-$ $0,17 \mathrm{~g} /$ hari. Rata-rata pertumbuhan berat harian yaitu 0,12 gram/hari. Dari hasil penelitian ini dapat dikatakan bahwa, pemberian pakan sistem feeding tray (anco) tidak efektif untuk pertumbuhan udang vannamei. Hal ini disebabkan oleh, pakan yang diberikan mengguakan sistem feeding tray tidak dapat dimakan secara merata oleh udang vannamei. Kekurangan pakan pada udang menyebabkan rendahnya pertumbuhan pada udang akibat kurangnya energi yang diperoleh dari pakan untuk kegiatan metabolisme dan kelebihan pakan juga dapat menyebabkan pertumbuhan rendah karena memerlukan energi yang besar untuk proses metabolisme sehingga pertumbuhan udang vaname terhambat akibat kekurangan energi. Menurut pendapat Khasani (2013) penyampaian informasi rangsangan oleh rambut-rambut aestetac sebagai organ sensorik, menurunnya rangsangan yang diterima rambut-rambut aestetac menyebabkan menurunnya respon udang dalam mencari dan mendekat pakan serta respon udang dalam menemukan dan memakan pakan yang diberikan. Udang memiliki pergerakan yang terbatas dalam mencari makanan sehingga pemberian pakan sistem feeding tray 
mempengaruhi sifat udang dalam mencari makanan. Udang vannamei memiliki sifat suka membenamkan diri di dasar petak, cenderung diam dan tidak semua udang aktif bergerak mencari pakan.

\section{Pakan Udang (FCR)}

Food Convertion Ratio (FCR) diartikan sebagai perbandingan antara berat pakan yang dimakan dengan pertambahan berat udang yang didapatkan. Pakan merupakan salah satu sumber nutrisi seperti pakan pellet yang terdiri dari protein, lemak, karbohidrat, vitamin dan mineral, nutrisi digunakan oleh udang vannamei (Litopenaeus vannamei) sebagai sumber energi untuk pertumbuhan dan kelulusan hidup serta mampu memberi asupan protein dari luar. Lingkungan seperti kualitas air mempengaruhi efektifitas pakan yang di konsumsi udang vannamei. Menurut pendapat (Effendi, 2003) bahwa kurang optimalnya kualitas air pada tambak akan mengakibatkan udang mengalami gangguan seperti nafsu makan menurun, terhambatnya proses moulting, dan mudah terserang penyakit. Hasil pengamatan rasio konversi pakan yang diperoleh selama pemeliharaan didapat berdasarkan perhitungan jumlahtotal pakan yang diberikan dengan bobot udang selama doc 105 hari pemeliharaan.

Berdasarkan hasil pengamatan konversi pakan selama pemeliharaan (Doc 105) memiliki nilai konversi pakan yang cukup tinggi yaitu FCR 3.3 yang artinya 3.3 $\mathrm{kg}$ pakan yang di berikan menghasilkan $1 \mathrm{~kg}$ udang. Nilai FCR didapatkan dari hasil biomassa akhir 944,02 kg udang dengan pakan yang dihabiskan 3.094,00 kg. Tingginya pakan yang dikonsumsi tidak sesuai dengan pertumbuhan udang dan mengakibatkan pemupukan bahan organik yang menjadi detritus pada perairan tambak, hal yang sama dinyatakan (Effendi, 2003), bahwa jumlah sisa pakan yang dikeluarkan bergantung pada kesesuaian komponen pakan dan kemampuan enzimatik pada saluran pencernaan udang. Dari pakan yang diberikan nilai FCR relatif tinggi karena melebihi nilai FCR yang efektif yaitu 1.1-1.5 (Mudjiman, 2007). Menurut Boyd dan Clay (2002), konversi pakan atau Feed Convertion Ratio (FCR) udang vannamei 1,3-1,4 (artinya untuk mendapatkan $1 \mathrm{~kg}$ udang dibutuhkan 1,3-1,4 kg pakan) Nilai FCR yang semakin kecil menunjukkan mutu pakan yang semakin baik yang mana tingkat kecernaan pakan tersebut semakin tinggi (Zainudin, et al., 2014). Dengan mengetahui nilai FCR pengeluaran biaya pembesaran udang vannamei (Litopenaeus vannamei) dapat dimanimalisir. Menurut pendapat (Subyakto et al. 2009) bahwa semakin kecil nilai FCR semakin baik karena hal ini menandakan semakin kecil biaya yang dikeluarkan untuk pembelian pakan sehingga semakin tinggi keuntungan yang diperoleh. Menurut Handajani (2008) bahwa besar kecilnya rasio konversi pakan dipengaruhi oleh beberapa faktor yaitu kualitas dan kuantitas pakan, spesies, ukuran dan kualitas air. Besar kecilnya rasio konversi pakan menentukan efektifitas pakan tersebut. Djarijah (2006) mengatakan bahwa pengukuran kualitas pakan dilakukan dengan membandingkan jumlah pakan yang diberikan dengan pertambahan berat udang yang dihasilkan dan dinyatakan sebagai FCR.

\section{Kelulusan hidup (SR)}

Kelulusan hidup atau kelangsungan hidup (SR) adalah perbandingan jumlah udang yang hidup hingga akhir pemeliharaan dengan jumlah udang yang hidup pada awal pemeliharaan (Zonneveld et al., 1991). Tingkat kelulus hidupan udang vannamei (Litopenaeus vannamei) yang diamati sampai dengan akhir penelitian pemanenan doc 105 hari disajikan pada Tabel 1:

Tabel 2. Kelangsungan Hidup (SR)

\begin{tabular}{|c|c|c|}
\hline $\begin{array}{c}\text { Populasi Akhir } \\
\text { (ekor) }\end{array}$ & $\begin{array}{c}\text { Jumlah Tebar } \\
\text { Awal (ekor) }\end{array}$ & R \\
\hline 74.652 & 165.636 & $45 \%$ \\
\hline
\end{tabular}

Berdasarkan Tabel 2 tingkat kelulusan hidup pada pemberian pakan sistemfeeding tray (anco) yaitu memiliki nilai SR 45\%. Pemberian pakan sistem feeding tray (anco) dapat dikategorikan memiliki tingkat kelulus hidupan atau kelangsungan hidup rendah seperti yang dinyatakan (Widigdo, 2013), Survival rate dikategorikan baik apabila nilai SR $>70 \%$, untuk SR kategori sedang 50-60\%, dan pada kategori rendah nilai SR $<50 \%$.

Rendahnya tingkat kelulus hidupan atau kelangsungan hidup udang vannamei (Litopenaeus vannamei) dapat dipengaruhi oleh udang yang kekurangan energi dalam memanfaatkan pakan. Menurut pendapat Anggoro (1992), kematian berkaitan dengan terjadinya gangguan osmolaritas internal, kehabisan energi dan berkurangnya daya pemanfaatan pakan. Faktor-faktor yang mempengaruhi tingginya prosentase kelangsungan hidup adalah faktor biotik dan abiotik seperti kompetitor, kepadatan populasi, penyakit, umur, kemampuan organisme dalam beradaptasi dan penanganan manusia (Effendie, 2003).

Berdasarkan hasil kelululus hidupan yang didapatkan dari penelitian ini rendah yaitu sebesar $45 \%$. Hal ini, disebabkan oleh rendahnya pertumbuhan berat dan panjang udang vannamei (Litopenaeus vannamei) yang dihasilkan selama pemeliharaan. Akan tetapi, nilai rasio konversi pakan atau Feed Convertion Ratio (FCR) diakhir pemeliharaan tinggi yaitu sebesar 3,3 melebihi standar nilai FCR yang baik, sehingga hal ini mempengaruhi nilai kelulus hidupan udang vannamei (Litopenaeus vannamei). Menurut Boyd dan Clay (2002), rasio konversi pakan atau Feed Convertion Ratio (FCR) udang vannamei 1,3-1,4 (artinya untuk mendapatkan $1 \mathrm{~kg}$ udang dibutuhkan 1,31,4 kg pakan) Nilai FCR yang semakin kecil menunjukkan mutu pakan yang semakin baik yang mana tingkat kecernaan pakan tersebut semakin tinggi (Zainudin, et.al, 
2014). Kebutuhan pakan harian dinyatakan sebagai tingkat pemberian pakan (feeding rate) perhari yang ditentukan berdasarkan persentase dari bobot udang (Effendi, 2004).

Rendahnya kelulusan hidup yang disebabkan oleh pertumbuhan berat dan panjang udang vannamei (Litopenaeus vannamei) yang rendah dipengaruhi oleh faktor, pakan yang diberikan menggunakan sistem feeding tray tidak dapat dimakan secara merata oleh udang vannamei, Menurut pendapat Khasani (2013) penyampaian informasi rangsangan oleh rambut-rambut aestetac sebagai organ sensorik, menurunnya rangsangan yang diterima rambut-rambut aestetac menyebabkan menurunnya respon udang dalam mencari dan mendekat pakan serta respon udang dalam menemukan dan memakan pakan yang diberikan. Udang memiliki pergerakan yang terbatas dalam mencari makanan dan memiliki sifat suka membenamkan diri di dasar petak, sehingga pemberian pakan sistem feeding tray mempengaruhi sifat udang dalam mencari makanan, karena pakan yang diberikan cenderung diam dan tidak menyebar secara merata.

\section{Kualitas Air Pemeliharaan Udang Vannamei (Litopenaeus vannamei)}

Menurut Cahyono (2009), faktor yang mempengaruhi tinggi rendahnya laju pertumbuhan udang vannamei dalam budidaya adalah faktor abiotik dan biotik. Faktor abiotik diantaranya adalah faktor fisika, kimia air suatu perairan atau sering disebut dengan kualitas air. Kualitas air yang baik akan menyebabkan proses fisiologi dalam tubuh udang berjalan dengan baik, sehingga mendukung pertumbuhan udang. Rata-rata kualitas air selama budidaya dapat dilihat pada Tabel 2, sebagai berikut:

Tabel 3. Hasil Pengamatan Parameter Kualitas Air

\begin{tabular}{|c|c|c|c|}
\hline \multicolumn{4}{|c|}{ Rata-rata Parameter Kualitas Air } \\
\hline Suhu ( C) & Salinitas (ppt) & $\mathrm{pH}$ & DO (mg/L) \\
\hline 29,99 & 21,37 & 8,45 & 7,26 \\
\hline
\end{tabular}

Berdasarkan Tabel 3 Hasil pengamatan parameter kualitas air dalam penelitian yang meliputi suhu, salinitas, $\mathrm{pH}$ dan DO yaitu:

a. Suhu $\left({ }^{0} \mathrm{C}\right)$

Menurut Sutanto (2005), suhu optimum dalam budidaya udang vannamei berkisar antara $23-30^{\circ} \mathrm{C}$. (Sartika S. 2005) menambahkan pertumbuhan rata-rata udang vannamei (Litopenaeus vannamei) akan mengalami penurunan jika suhu kurang dari $23{ }^{\circ} \mathrm{C}$ atau lebih dari $30^{\circ} \mathrm{C}$. Menurut Hudi (2005), suhu air dapat mempengaruhi sintasan, pertumbuhan, reproduksi, tingkah laku, pergantian kulit, dan metabolisme. Rata-rata suhu air selama pemeliharaan udang vannamei (Litopenaeus vannamei) yaitu $29,99^{\circ} \mathrm{C}$. Berdasarkan hasil pengamatan kualitas air selama pemeliharaan udang dapat dikatakan baik dan coc ok untuk budidaya udang vannamei (Litopenaeus vannamei).

\section{b. Salinitas (ppt)}

Menurut Nababan et al. (2015) yang menyatakan bahwa salinitas yang baik untuk pertumbuhan berkisar antara 10-30 ppt. (Supito, 2017) menambahkan udang vannamei menyukai salinitas yang tidak terlalu tinggi, yaitu optimum pada salinitas $20-40$ ppt. Rata-rata salinitas selama pemeliharaan udang vannamei (Litopenaeus vannamei) yaitu 21,37 ppt. Berdasarkan hasil pengamatan kualitas air selama pemeliharaan udang dapat dikatakan baik dan cocok untuk budidaya udang vannamei (Litopenaeus vannamei).

c. $\mathrm{pH}$

Menurut pernyataan Amirna et al. (2013) yang menyatakan bahwa nilai $\mathrm{pH}$ yang normal untuk pertumbuhan udang vannamei adalah berkisar antara 7,58,5 . Rata-rata $\mathrm{pH}$ selama pemeliharaan udang vannamei Llitopenaeus vannamei) yaitu 8,45. Berdasarkan hasil pengamatan kualitas air selama pemeliharaan udang dapat dikatakan baik dan cocok untuk budidaya udang vannamei (Litopenaeus vannamei).

\section{d. DO (mg/l)}

Menurut Amri dan Iskandar (2008) dalam Amirna et al. (2013) yang menyatakan bahwa kandungan oksigen terlarut yang baik untuk kehidupaan udang vannamei adalah 4-8 mg/l. Rata-rata $\mathrm{pH}$ selama pemeliharaan udang vannamei (Litopenaeus vannamei) yaitu 7,26. Berdasarkan hasil pengamatan kualitas air selama pemeliharaan udang dapat dikatakan baik dan cocok untuk budidaya udang vannamei (Litopenaeus vannamei).

\section{Kesimpulan}

Berdasarkan hasil penelitian laju pertumbuhan dan kelulusan hidup udang vannamei (Litopenaeus vannamei) dengan sistem feeding tray (anco) dapat disimpulkan bahwa 1). Penggunaan sistem pemberian pakan feeding tray (anco) memiliki nilai laju perumbuhan berat (MBW) sebesar 0,89 gram, panjang harian (SGR) $0.0108 \mathrm{~cm}$ dan laju pertumbuhan berat harian (ADG) sebesar 0,12 gram, serta rasio konversi pakan (FCR) sebesar 3.3. Nilai FCR ini melebihi nilai FCR yang efektif yaitu1,1-1,5. 2). Kelulus hidupan (SR) yang dihasilkan pada akhir penelitian ini dapat dikatagorikan rendah yaitu sebesar $45 \%$.

\section{Ucapan Terima Kasih}

Penulis menyampaikan terima kasih kepada semua pihak yang telah terlibat dalam proses kegiatan ini baik secara langsung maupun tidak langsung. 


\section{Referensi}

Amirna, O., R. Iba \& A. Rahman. (2013). Pemberian Silase Ikan Gabus pada Pakan Buatan bagi Pertumbuhan dan Kelangsungan Hidup Udang Vaname (Litopenaeus vannamei) pada Stadia Post Larva. Jurnal Mina laut Indonesia, 01 (01): 93-103 ISSN: 2303-3959. Universitas Haluoleo Kampus Hijau Bumi Tridarma. Kendari. http://ojs.uho.ac.id/index.php/minalaut/article/vie $\underline{w} / 81$.

Anggoro, S. (1992). Efek Osmotik Berbagai Tingkat Salinitas Media Terhadap Daya Tetas Telur dan Vitalitas Larva Udang Windu (Pennaeus monodon Fabricius). Disertasi, Program Pasca Sarjana Institut Pertanian Bogor, Bogor.

Arsad, Sulastri et al. (2017). Studi Kegiatan Budidaya Pembesaran Udang Vaname (Litopenaeus Vannamei) dengan Penerapan Sistem Pemeliharaan Berbeda. J I P K. 9 (1) : 1-14. DOI: http://dx.doi.org/10.20473/jipk.v9i1.7624.

Babu, D., Ravuru \& J.N. Mude. (2014). Effect of Density on Growth and Production of Litopenaeus vannamei of Brackish Water Culture System in Summer Season with Artificial Diet in Prakasam District, India. American International Journal of Research in Formal, Applied, \& Natural Sciences. 5(1):10-13. ISSN (Print): 2328-3777, ISSN (Online): 2328-3785, ISSN (CD-ROM): 23283793. http://iasir.net/aijrfansissue/aijrfansissue5. html.

Boyd, C.E. \& Clay, J.W. (2002). Evaluation of Belize Aquaculture LTD, A Superintensive Shrimp Aquaculture System. Report prepared under The World Bank, NACA, and FAO Consorsium. Work in progress for Public Discussion. Published by The Consorsium Network of Aquaculture Centres in Asia-Pacific (NACA). Pp: 17. https://enaca.org/?id=517.

Cahyono, B. (2009). Budidaya Biota Air Tawar. Kanisius. Yogyakarta. ISBN: 9786027573024, pp: 200.

Cing, C.A. \& Limsuwan, C. (2012). Feed Trays or Broadcasting. Global Aqua Culture Advocute, 2 September (2012). pp. 44-45. https://www.aquaculturealliance.org/advocate/fee d-trays-or-broadcasting/.

Dinas Kelautan dan Perikanan Kab. Sumbawa. (2014). Laporan Tahunan. Hal 17-19. https://www.sumbawakab.go.id/skpd/24/dinas-

kelautan-dan-perikanan.html.

Djarijah, A.S. (2006). Pakan Ikan Alami. Kanisius. Yogyakarta. ISBN: 979-497-441-2, pp: 86.

Effendi, H. (2003). Telahan Kualitas Air Bagi Pengelolaan Sumber daya Lingkungan Perairan. Kanisius. Yogyakarta. ISBN: 978-979-21-0613-8, pp: 250

Gunarto \& Hendrajat, E.A. (2008). Budidaya Udang Vanamei, Litopenaeus Vannamei Pola Semi Intensif dengan Aplikasi Beberapa Jenis Probiotik Komersial. Jurnal Riset Akuakultur, 3 (3): 339349. DOI: http://dx.doi.org/10.15578/jra.3.3. $\underline{\text { 2008.339-349 }}$

Halim (2019). Genjot Potensi Ekspor Udang Indonesia, Lim Shrimp Organizational (LSO) Indonesia, Tanda tangani Kontrak dengan JD.COM dan ecMAX. https://dmagz.id/umum/genjot-potensiekspor-udang-indonesia-lim-shrimp-organizational-lso-indonesia-tandatangani-kontrak-kerjasamadengan-jd-com-dan-ecmax/ (Accessed on Agustus 13, 2019).

Haliman R.W \& D. Adijaya (2005). Klasifikasi dan Morfologi Udang Vaname. Penebar Swadaya. Jakarta. ISBN: 978-60298295-0-1, pp: 75

Handajani, Hany (2006). Pengujian Tepung Azolla Terfermentasi Sebagai Penyusun Pakan Ikan Terhadap Pertumbuhan dan Daya Cerna Ikan Nila Gift (Oreochiomis sp). Jurnal Gamma Fakultas Perikanan. 1 (2) September 2006: 162 - 170. http://ejournal.umm.ac.id/index.php/gamma/articl e/view/76.

Hermawan, D. (2012). Teknik Pemeliharaan Larva Udang Windu (Penaeus monodon) di HSRT. Proposal Praktek Kerja Lapang II Jurusan Teknologi Budidaya Perikanan. Jawa Timur: Akademi Perikanan Sidoarjo.

Hikmayani, Y., M. Yulisti \& Hikmah (2012). Evaluasi Kebijakan Peningkatan Produksi Perikanan Budidaya. Jurnal Kebijakan Sosial Ekonomi Kelautan dan Perikanan. 2 (2): 85-102. DOI: http://dx.doi.org/10.15578/jksekp.v3i1.235

Hudi L. \& Shahab A. (2005). Optimasi Produktifitas Budidaya Udang Vaname Litopenaeus vannamei dengan Menggunakan Metode Respon Surface dan Non Linier Programming. Institut Teknologi Sepuluh Nopember. Surabaya. 
http://digilib.its.ac.id/ITSMaster3100006025362/6 $\underline{68}$.

Karuppasamy, A., V. Mathivanan \& Selvisabhanayakam (2013). Comparative Growth Analysis of Litopenaeus vannamei in Different Stocking Density at Different Farms of the Kottakudi Estuay, South East Coast of India. International Journal of Fisheries and Aquatic Studies. 1(2) Part A, pp: 40-44. ISSN: 2347-5129. http://www.fisheriesjournal.com/archives/?year=2 $\underline{013 \& \text { vol }=1 \& \text { issue }=2 \& \text { part }=\text { A\&ArticleId }=18}$

Khasani, I. (2013). Atraktan Pada Pakan Ikan: Jenis, Fungsi dan Respon Ikan. Media Akuakultur. 8(3) : 127-133. DOI: http://dx.doi.org/10.15578/ma.8.2. $\underline{\text { 2013.127-133 }}$

Mangampa, Markus \& Hidayat Suryanto Suwoyo. (2010). Budidaya Udang Vaname (Litopenaeus Vannamei) Teknologi Intensif Menggunakan Benih Tokolan. J. Ris. Akuakultur. 5 (3): 351-361. DOI: http://dx.doi.org/10.15578/jra.5.3. 2010.351-361

Mansyur, A. \& Suwoyo, H.S. (2012). Pengaruh pergiliran pakan kandungan protein berbeda terhadap pertumbuhan, sintasan dan produksi udang vaname (litopenaeus vannamei) semi-intensif. Proceeding IndoAqua-Forum Inovasi Teknologi Akuakultur, 2012. (461-468). DOI: http://ejournalbalitbang.kkp.go.id/index.php/fita/a $\underline{\text { rticle/view/4127 }}$

Mansyur, A., Pantjara, B. \& Suwoyo, H.S. (2013). Pengembangan Budidaya Udang Vaname, Litopenaeus vannamei Intensif Melalui Teknik Aplikasi Pergiliran Pakan. Laporan kegiatan penelitian di Instalasi tambak percobaan, Punaga. BPPBAP. 13 hal https://bppbapmaros.kkp.go.id/ ?s=Pengembangan+Budidaya+Udang+Vaname $\%$ 2C+Litopenaeus+vannamei+Intensif+Melalui+Te knik+Aplikasi+Pergiliran+Pakan.+Laporan+kegia tan+penelitian+di+Instalasi+tambak+percobaan.

Mudjiman, A. (2007). Makanan Ikan (Pengetahuan Lengkap Tentang Jenis-Jenis Makanan Ikan, Cara Memproduksi, dan Aplikasinya) - edisi revisi. Penebar Swadaya. Jakarta. ISBN: 979-8031-14-8, pp: 192.

Nababan, E., Putra I. \& Rusliadi (2015). Pemeliharaan Udang Vaname (Litopenaeus Vannamei) dengan Persentase Pemberian Pakan Yang Berbeda. Jurnal Ilmiah Perikanan dan Kelautan 3 (2): 18-26, https://media.neliti.com/ media/publications/199011-the-maintenance-of-

white-shrimp-litopena.pdf.

Nunes, A.J.P. \& Suresh, A.V. (2001). Feeding Tray technique - Improves Shrimp Feed Management in Brazil. The Advocate, Feb 2001 Global Aquaculture Alliance, Brazil, pp: 25-26. https://www.aquaculturealliance.org/?s=Improves +shrimp+feed+management+in+Brazil\&post typ $\underline{\mathrm{e}=\& \mathrm{cat}}=$.

Pemerintah Kabupaten Sumbawa (2019). Kabupaten Sumbawa dalam angka tahun 2019. Sumbawa.

Poernomo, A. (1992). Site Selection for Coastal Shrimp Fonds. Fisheries Research and Development Project Water Quality. Field Guide for Writing Soil Profile Dede et al, Evaluasi Tingkat Kesesuaian 37 Descriptions. Sukabumi, January 22 - February 8 1992. Pp: 1-15.

Rangka, Nur Ansari \& Gunarto. (2012). Pengaruh Penumbuhan Bioflok Pada Budidaya Udang Vaname Pola Intensif di Tambak. Jurnal Ilmiah Perikanan dan Kelautan. 4 (2): 141-149. DOI: http://dx.doi.org/10.20473/jipk.v4i2.11565

Sartika S. (2005). Metode Penelitian Air. Usaha Nasional. Surabaya. ISBN: 0795784, pp: 309

Subyakto, Slamet, Dede Sutende, Moh. Afand \& Sofiati (2009). Budidaya Udang Vannamei (Litopenaeus vannamei) Semiintensif dengan Metode Sirkulasi Tertutup Untuk Menghindari Serangan Virus [The Semiintensive Culture of Litopenaeus vannamei by Closed Circulation Method To Prevent Virus Attack]. Jurnal Ilmiah Perikanan dan Kelautan (Jipk)/Scientific Journal Of Fisheries And Marine. $1 \quad$ (2), pp: 121-127. DOI: http://dx.doi.org/10.20473/jipk.v1i2.11677.

Supito (2017). Petunjuk Teknis Budidaya Udang Vannamei (Litopenaeus Vannamei). Balai Besar Perikanan Budidaya Air Payau (BBPBAP) Jepara. ISBN: 978-602-61170-3-8, pp: 25.

Supono \& Wadiyanto (2008). Evaluasi Budidaya Udang Putih (Litopenaeus vannamei) dengan Meningkatkan Kepadatan Tebar di Tambak Intensif. Seminar Hasil Penelitian \& Pengabdian kepada Masyarakat Universitas Lampung. pp 237242. ISBN: 978-979-18755-0-9.

Supono (2017). Molting dan Perubahan Perilaku pada Udang. Plantaxia. Yogyakarta. ISBN: 97860298295-0-1, pp: 169. 
Sutanto, I. (2005). Kesuksesan Budidaya Udang Vannamei (Litopenaeus vannamei) di Lampung. dalam A. Sudrajat, Azwar, Z.I., Hadi, L.E, Haryanti, Giri, N.A. \& Sumiarsa, G.S. (2005). Buku Perikanan Budidaya Berkelanjutan. Pusat Riset Perikanan Budidaya. KKP-Badan Riset Kelautan dan Perikanan. Jakarta ISBN: 9798186974, pp: 67-72. http://perpustakaan.kkp.go.id/knowledgerepositor y/index.php? $\mathrm{p}=$ show detail\&id=808.

Syafaat, Muhammad Nu. Abdul Mansyur, Syarifuddin Tonnek \& Muhammad Chaidir Undu (2016). Persentase Sisa Pakan Protein Tinggi dan Rendah Ddi Anco (Feeding Tray) Pada Budidaya Udang Vaname (Litopenaeus Vannamei) Intensif Dengan Teknik Pergiliran Pakan. Prosiding Forum Inovasi Teknologi Akuakultur. Balai Penelitian dan Pengembangan Budidaya Air Payau. pp 667-676. http://ejournal-balitbang.kkp.go.id/index.php/fita/ article/view/1877.

Widigdo, B. (2013). Bertambak Udang dengan Teknologi Biocrete. Kompas Media Nusantara. Jakarta. ISBN: 978-979-709-698-4, pp: 104. 